\title{
Reinterpretacja tektoniki w obszarze Pomorza Zachodniego w oparciu o nową wersję profilu sejsmicznego 2D po reprocessingu
}

\section{Reinterpretation of tectonics in the Western Pomeranian area (Northern Poland) based on the new version of the $2 \mathrm{D}$ seismic section after reprocessing}

\author{
Łukasz Bajewski, Aleksander Wilk, Andrzej Urbaniec, Robert Bartoń \\ Instytut Nafty i Gazu - Państwowy Instytut Badawczy
}

\begin{abstract}
STRESZCZENIE: W niniejszym artykule zaprezentowano wyniki reprocessingu sejsmiki 2D z rejonu Pomorza Zachodniego. Celem reprocessingu była dalsza poprawa obrazowania utworów i struktur podcechsztyńskich. Uzyskane we wcześniejszym etapie wyniki przetwarzania sejsmicznego, pomimo pewnej poprawy w porównaniu do wersji archiwalnej, nadal nie pozwalają na wiarygodną interpretację strukturalną (a tym bardziej facjalną) w obrębie utworów podcechsztyńskich. Reprocessing wykonano w wersji migracji po składaniu (poststack) na podstawie sekwencji przetwarzania opracowanej w Zakładzie Sejsmiki Instytutu Nafty i Gazu - Państwowego Instytutu Badawczego. Nowymi elementami zastosowanej obecnie sekwencji przetwarzania było szczegółowe podejście do wyliczenia poprawek statycznych na każdym z zarejestrowanych w wyniku akwizycji rekordów sejsmicznych. Ponadto wykonano analizę pola prędkości użytego w procesie sumowania (na kolekcjach CMP), dającego możliwość wyliczenia resztkowych poprawek statycznych w bramkach czasowych, dobieranych na podstawie analizy kątów nachylenia refleksów na sekcji sejsmicznej. Modyfikacji uległo również pole prędkości do czasowej migracji po składaniu. Migrację tą zrealizowano w oparciu o bieżące analizy prędkości oraz pole prędkości opracowane na podstawie pomiarów PPS (pionowe profilowania sejsmiczne), które ze względu na metodykę pomiaru zawierają informację o anizotropii ośrodka geologicznego. Zapis sejsmiczny analizowanego profilu uzyskany na obecnym etapie ujawnia nowe szczegóły obrazu geologicznego w stosunku do wcześniejszego opracowania, zarówno w budowie tektonicznej, strukturalnej, jak i facjalnej. Widoczne jest to głównie w utworach permsko-mezozoicznych. W utworach podcechsztyńskich poprawa jest również zauważalna, niemniej jednak nadal nie jest to obraz wystarczający do szczegółowej interpretacji. Główną przyczyną braku czytelnego i wiarygodnego obrazu strukturalnego w zapisie sejsmicznym dla utworów podcechsztyńskich jest brak poprawnego rozkładu prędkości w tych utworach, wynikający z niedostatecznej ilości danych. Wyniki tej pracy pokazują możliwości poprawy jakości archiwalnych profili sejsmicznych z badanego rejonu w wyniku reprocessingu. Zdaniem autorów kluczem do uzyskania szczegółowego obrazu sejsmicznego w obrębie utworów podcechsztyńskich jest zastosowanie poprawnego pola prędkości.
\end{abstract}

Słowa kluczowe: migracja poststack, prędkości składania, model prędkości, PPS.

ABSTRACT: This article presents the results of the second part of the work on reprocessing of 2D seismic in the West Pomeranian region. The purpose of reprocessing was to further improve the imaging of under-Zechstein formations and structures. The obtained seismic processing results in the previous stage, although they were better than those obtained on the archival version still do not allow for their reliable structural (as well as facial) interpretation. Reprocessing was performed in post stack migration based on the processing sequence developed at the Seismic Department of the Oil and Gas Institute - National Research Institute. New elements of the currently used processing sequence consisted of a detailed approach to calculate static corrections on each of the registered seismic records and an analysis of the velocity field used in the summation process (on CMP gathers), giving the possibility to calculate residual static corrections in time gates, selected on the basis of dip angle analysis of the reflections in the seismic section. The velocity field for post stack time migration has also been modified. Post stack time migration was based on the current velocity analysis and velocity field obtained on the basis of VPS measurements (vertical seismic profiling), which due to the measurement methodology, contain information about the anisotropy of the geological environment. Seismic image of the analyzed profile obtained at current stage reveals new details of the geological structure compared to the previous study, both in tectonic, structural and facial view. This is mainly visible in Permian-Mesozoic formations. Improvement is also visible in the under-Zechstein deposits, but this seismic image is not still enough for a detailed interpretation. The main reason for the lack of a clear and reliable structural image in the seismic record for under-Zechstein deposits is the lack of correct velocity distribution in these formations, which results from insufficient data. The results of this work show the possibilities of improving the quality of archival seismic sections the studied

Autor do korespondencji: Ł. Bajewski, e-mail: lukasz.bajewski@inig.pl

Artykuł nadesłano do Redakcji: 02.12.2019 r. Zatwierdzono do druku: 01.06.2020 r. 
region as a result of reprocessing. According to the authors, the key to obtaining a detailed seismic image within the sunder-Zechstein formations is the use of the correct velocity model.

Key words: poststack migration, stacking velocities, velocity model, VSP.

\section{Wstęp}

Niniejszy artykuł jest prezentacją wyników drugiego etapu prac, obejmującego poprawę obrazowania struktur podcechsztyńskich na podstawie reprocessingu sejsmiki 2D w rejonie Pomorza Zachodniego. Pomimo poprawy, jaką uzyskano w pierwszej części prac (Bajewski et al., 2018b), obraz sejsmiczny w obrębie utworów podcechsztyńskich nie jest wystarczająco czytelny dla interpretacji strukturalnej. Autorzy podjęli kolejną próbę reprocessingu, koncentrując się głównie na możliwie najbardziej precyzyjnym obliczeniu poprawek statycznych oraz modyfikacji pola prędkości do migracji czasowej po składaniu. Niewielkie zmiany zostały również wprowadzone do użytej w poprzednim etapie i opracowanej w Zakładzie Sejsmiki Instytutu Nafty i Gazu - Państwowego Instytutu Badawczego sekwencji przetwarzania (Bajewski et al., 2016, 2017b, 2018a, 2018b). Zastosowane w tej części prac poprawki statyczne, tzw. refrakcyjne, wyliczono na podstawie pierwszych wstapień zarejestrowanych na rekordach sejsmicznych. Na każdym rekordzie sejsmicznym określono liczbę refraktorów, co pozwoliło na znacznie lepsze rozwiązanie zagadnienia statyki w stosunku do pierwszego etapu prac. Analiza pola prędkości użytego w procesie sumowania (na kolekcjach CMP) dała możliwość wyliczenia resztkowych poprawek statycznych w bramkach czasowych, dobieranych na podstawie analizy kątów nachylenia refleksów na sekcji sejsmicznej. Migrację po składaniu zrealizowano w oparciu o pole prędkości składania oraz pole prędkości, opracowane w pierwszym etapie prac, na podstawie pomiarów PPS (pionowe profilowania sejsmiczne), które ze względu na metodykę pomiaru zawierają informację o anizotropii ośrodka geologicznego. Sposób budowy pola prędkości na potrzeby migracji po składaniu na podstawie pomiarów PPS został opracowany w pracach statutowych (Bajewski et al., 2017b; Wilk et al., 2017).

\section{Krótka charakterystyka geologiczna rejonu badań}

Analizowany profil sejsmiczny zlokalizowany jest w obszarze Pomorza Zachodniego. Biorąc pod uwagę jednostki tektoniczne, badany rejon znajduje się w strefie tzw. szwu transeuropejskiego (Trans-European Suture Zone, TESZ), biegnącego wzdłuż krawędzi kratonu wschodnioeuropejskiego (vide Pharaoh, 1999; Grad et al., 2002; Nawrocki i Poprawa, 2006) i stanowiącego obszar graniczny pomiędzy prekambryjską platformą wschodnioeuropejską a zachodnioeuropejską platformą paleozoiczną (rys. 1). Natomiast w odniesieniu do mezozoicznego piętra strukturalnego rejon ten leży na terenie pomorskiego segmentu antyklinorium śródpolskiego (Żelaźniewicz et al., 2011).

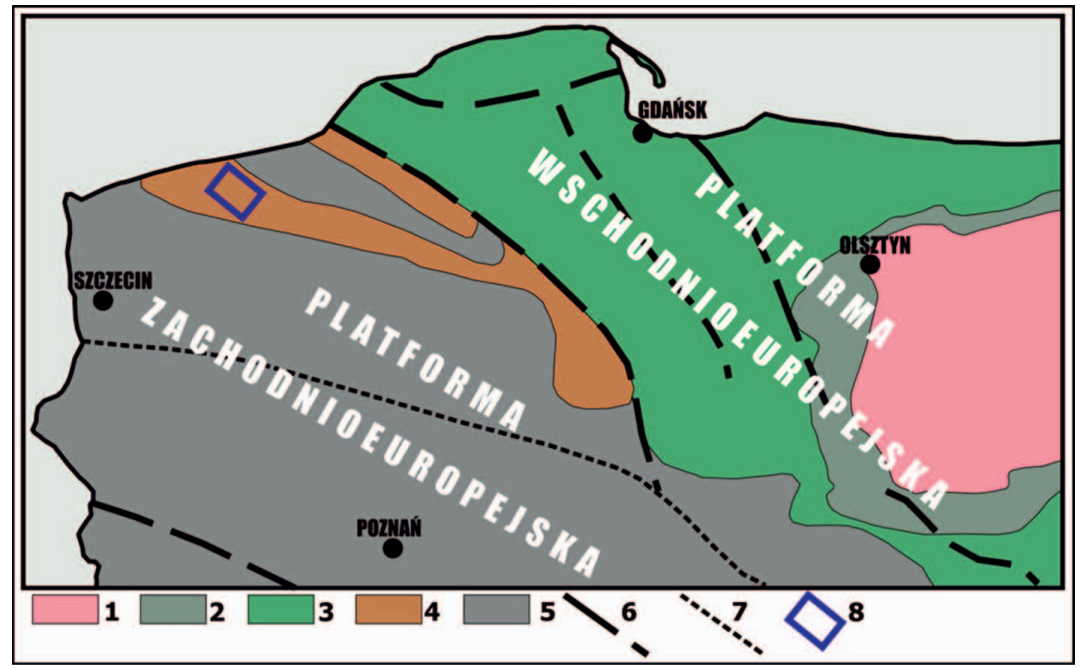

Rys. 1. Mapa głównych jednostek tektonicznych Polski pod pokrywą permskomezozoiczną i kenozoiczną (wg Żelaźniewicza et al., 2011); 1 - podłoże krystaliczne, 2 - kambr, 3 - ordowik-sylur, 4 - dewon, 5 - karbon, 6 - główne strefy dyslokacji, 7 - zasięg zapadliska przedgórskiego waryscydów, 8 - lokalizacja obszaru badań

Fig. 1. Map of the main Polish tectonic units under the Permian - Mesozoic and Cenozoic cover (according to Żelaźniewicz et al., 2011); 1 - crystalline basement, 2 - Cambrian, 3 - Ordovician-Silurian, 4 - Devonian, 5 - Carboniferous, 6 - main dislocation zones, 7 - the range of the Variscan foredeep basin, 8 - localization of the research area
Bardziej szczegółowa budowa geologiczna obszaru badań, obejmująca poszczególne piętra strukturalne analizowanego rejonu wraz z obowiązującymi podziałami litostratygraficznymi, przedstawiona została w pracy statutowej Bajewskiego et al. (2018b).

W obrębie analizowanego rejonu wyróżnić można trzy główne piętra strukturalne. Najniższe piętro stanowi paleozoik, reprezentowany przez dewon i karbon, których utwory tworzą skomplikowaną mozaikę powstałą z różnego ich wieku, świadczącą o istnieniu w podłożu cechsztynu szeregu odrębnych bloków tektonicznych, utworzonych w wyniku zdarzeń 
tektonicznych i erozyjnych, jakie miały miejsce w obszarze basenu pomorskiego w czasie późnego dewonu, karbonu oraz permu. Przypuszczalnie znaczna część osadów dewonu i karbonu została usunięta przez kolejne etapy erozji, będące następstwem stopniowego dźwigania się obszaru pomorskiego (vide Dadlez, 1978; Matyja, 1993; Matyja et al., 2000). Istotnym aspektem budowy geologicznej Pomorza jest również wyraźne pierwotne zróżnicowanie miąższości utworów dewonu i karbonu, wynikające ze zróżnicowanej i zmiennej w czasie subsydencji, jaka miała miejsce w obrębie poszczególnych bloków tektonicznych (Matyja, 1993, 2006; Świdrowska i Hakenberg, 1996; Matyja et al., 2000). Na utworach paleozoicznych zalegają utwory dolnego permu (czerwonego spągowca). Perm górny (cechsztyn) tworzą cztery główne cyklotemy: PZ1, PZ2, PZ3 i PZ4. Starsze cykle sedymentacyjne mają charakter węglanowo-ewaporatowy, natomiast cykl najmłodszy ma charakter klastyczno-ewaporatowy. Cykliczność trzech najstarszych cyklotemów (PZ1, PZ2, PZ3) związana jest ze zmianami transgresywno-regresywnymi morza cechsztyńskiego, podczas gdy cykliczność najmłodszego cyklotemu PZ4 wynika głównie z cyklicznych zmian klimatu, gdyż w okresach wilgotnych występowała sedymentacja utworów terygenicznych, natomiast w okresach suchych - utworów ewaporatowych (Wagner, 1994). Utwory cechsztynu przykrywa piętro mezozoiczne, zaczynające się utworami triasu, reprezentowanymi przez pstry piaskowiec, wapień muszlowy, kajper i retyk. Mezozoik kończy się utworami dolnej jury. Utwory kenozoiczne są reprezentowane przez czwartorzęd.

\section{Przetwarzanie sejsmiczne (reprocessing)}

Przetwarzanie sejsmiczne wykonano w systemie SeisSpace (ProMax) - Seismic Processing and Analysis Release 5000.10.0.1. Do przetwarzania ww. profilu wykorzystana została sekwencja przetwarzania, którą opracowano w INiG - PIB w ramach realizacji prac statutowych (Bajewski et al., 2016, 2017b, 2018b).

Blokowy schemat głównych procedur sekwencji przetwarzania przedstawiony został na rysunku 2 .

\section{Budowa pola prędkości do migracji czasowej po składaniu}

Do migracji czasowej po składaniu wykorzystano pole prędkości składania otrzymane w procesie bieżących analiz prędkości (rys. 3) oraz pole prędkości uzyskane na podstawie pionowych profilowań sejsmicznych PPS (Bajewski et al.,

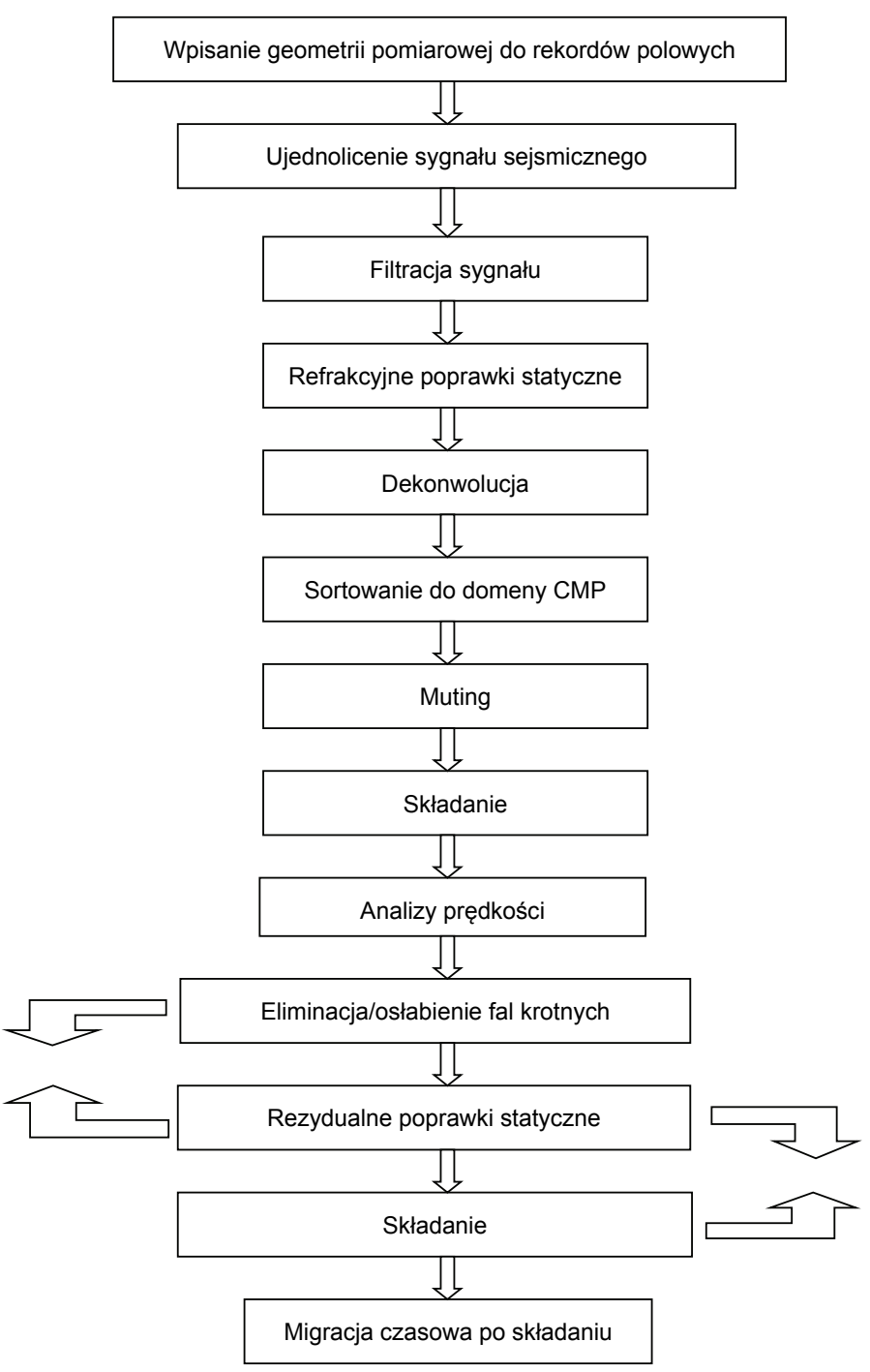

Rys. 2. Blokowy schemat sekwencji przetwarzania

Fig. 2. Block diagram of processing sequence

2019) (rys. 4). Ze względu na fakt, że pionowe profilowania sejsmiczne PPS zawierają informację o anizotropii prędkości (Grechka et al., 2007; Pevzner et al., 2009) zastosowanie modelu prędkości uzyskanego $\mathrm{z}$ danych PPS dało bardzo dobre efekty w przypadku migracji czasowej po składaniu dla profilu sejsmicznego z rejonu Karpat (Bajewski et al., 2017a). Szczegółowy opis budowy pola prędkości na potrzeby migracji czasowej po składaniu przy użyciu pionowych profilowań sejsmicznych został opisany w pracy statutowej Bajewskiego et al. (2018b). Pole prędkości składania uzyskane w procesie bieżących analiz prędkości przeliczono na prędkości interwałowe i poddano kalibracji modelem prędkości otrzymanym z pionowych profilowań sejsmicznych PPS (policzone przy użyciu algorytmu rozkładu metodą Gaussa) (rys. 4). Uzyskany w ten sposób rozkład prędkości interwałowych (rys. 5) wykorzystano do migracji czasowej po składaniu. 


\section{NAFTA-GAZ}

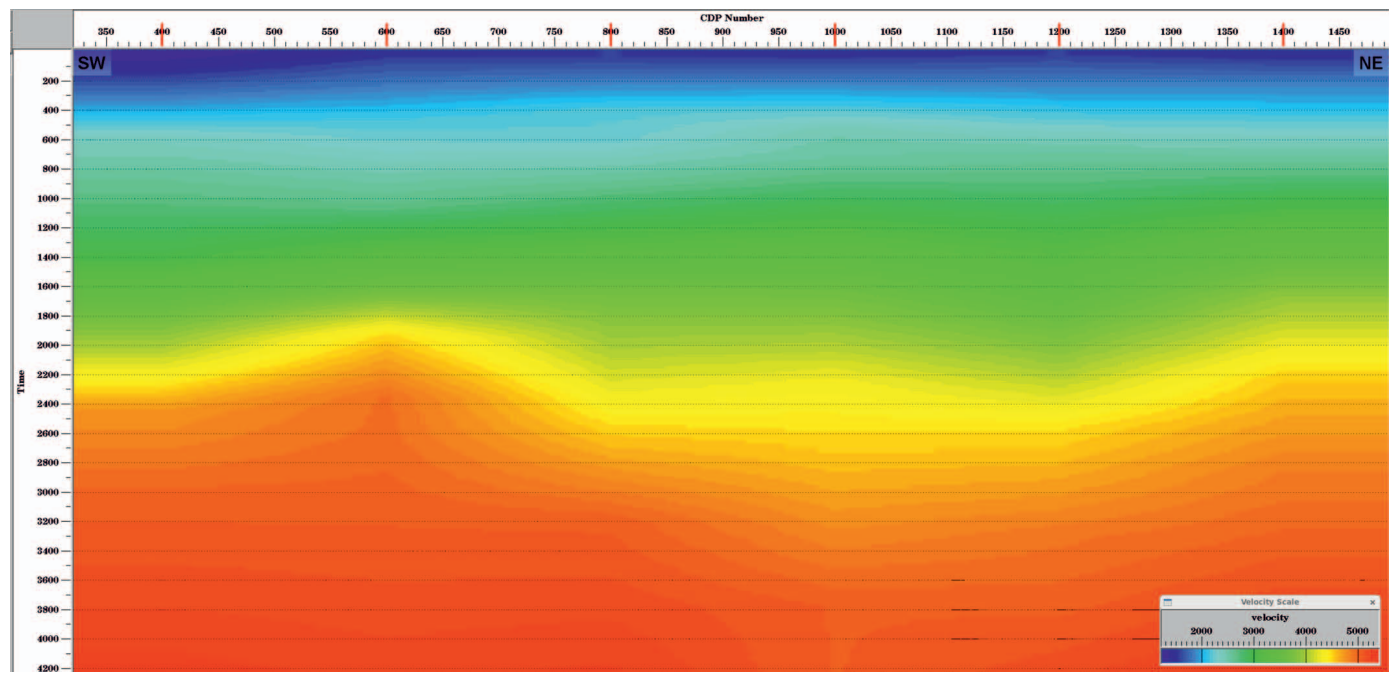

Rys. 3. Profil sejsmiczny nr 1. Rozkład prędkości interwałowych otrzymanych z analiz prędkości

Fig. 3. Seismic section No. 1. Distribution of interval velocities from velocity analyses

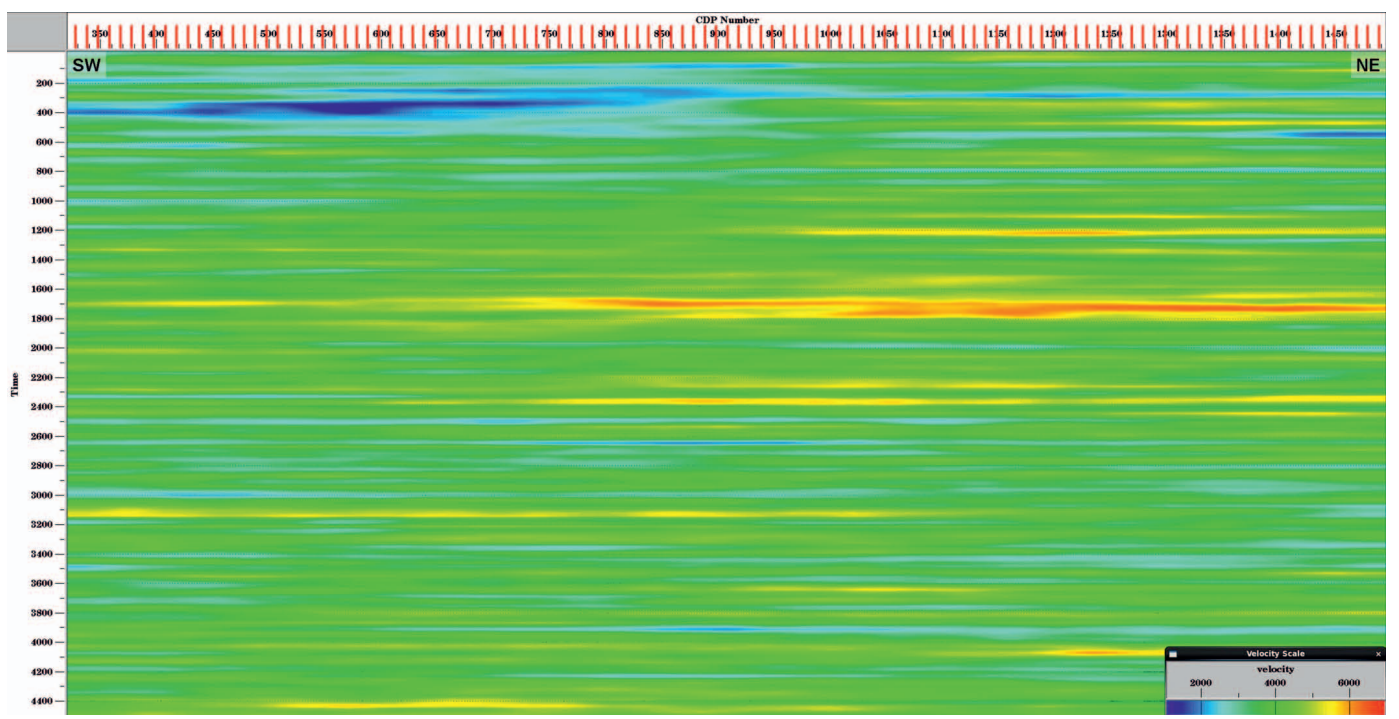

Rys. 4. Profil sejsmiczny nr 1. Rozkład prędkości interwałowych dla miąższości warstwowania 10 m uzyskany algorytmem rozkładu Gaussa

Fig. 4. Seismic section No. 1. Distribution of interval velocities for layering thickness of $10 \mathrm{~m}$, based on the Gaussian distribution algorithm

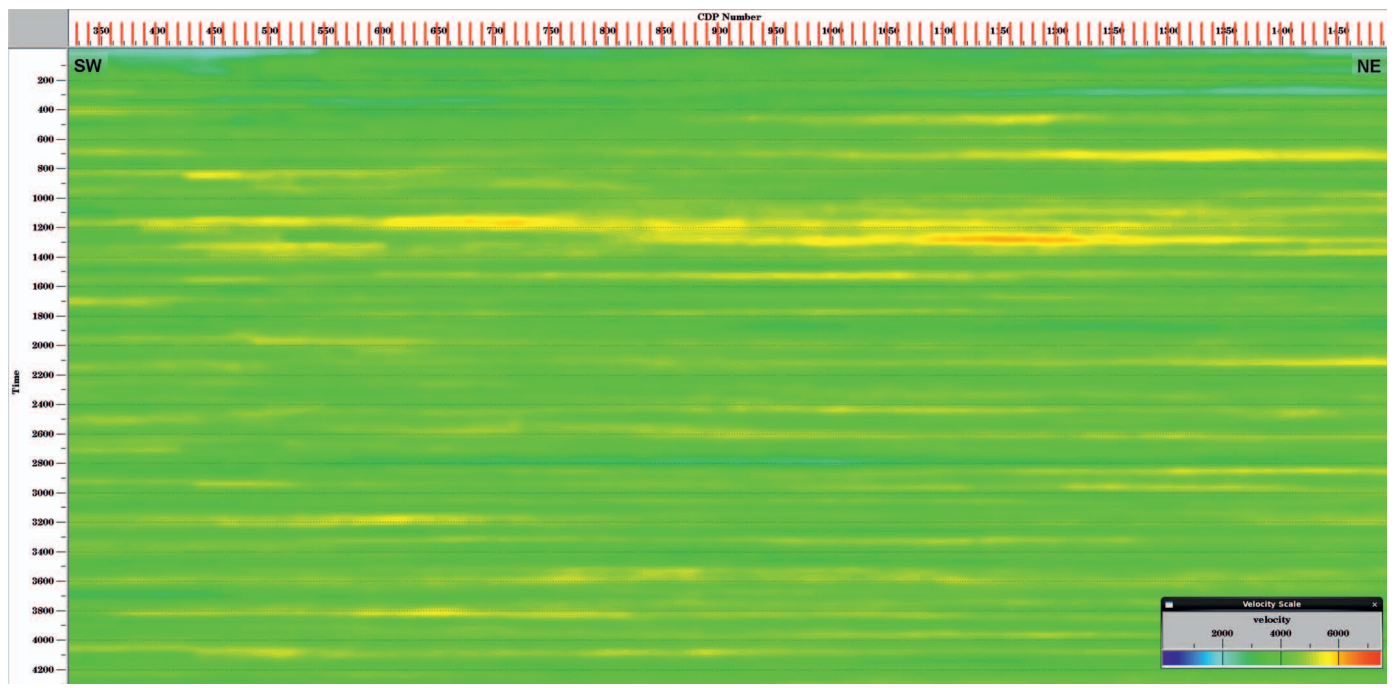

Rys. 5. Profil sejsmiczny nr 1. Rozkład prędkości interwałowych wykorzystany na potrzeby migracji czasowej po składaniu

Fig. 5. Seismic section No. 1. Distribution of interval velocities used for the post stack time migration 


\section{Analiza otrzymanych wyników}

\section{Dowiazanie danych sejsmicznych do danych otworowych}

Uzyskany obraz sejsmiczny został sprawdzony pod kątem dopasowania danych sejsmicznych do danych otworowych. W tym celu obliczono sejsmogram syntetyczny w najbliżej położonym w stosunku do profilu otworze W-1, który został porównany z otrzymanym obrazem sejsmicznym. Rysunek 6 przedstawia dopasowanie bieżącego obrazu sejsmicznego i trasy syntetycznej uzyskanej w tym otworze, a rysunek 7 - fragment profilu z otrzymaną trasą syntetyczną. Dopasowanie danych jest bardzo dobre, co pozwoliło na dowiązanie korelowanych granic:
- TkV (Tk3G) - odbicie od spągu retyku / stropu kajpru, śledzone po maksimum amplitudowym;

- TmV - odbicie od stropu wapienia muszlowego, śledzone po maksimum amplitudowym;

- Z4 (Na4) - odbicie od stropu cechsztynu, śledzone po minimum amplitudowym;

- A3 str - odbicie od stropu anhydrytu głównego, korelowane po maksimum amplitudowym;

- A2_str - odbicie od stropu anhydrytu podstawowego, korelowane po maksimum amplitudowym;

- Zsp (P1) - odbicie od spągu cechsztynu, korelowane po minimum amplitudowym;

- Cstr (C) - odbicie od stropu karbonu, korelowane po maksimum amplitudowym.

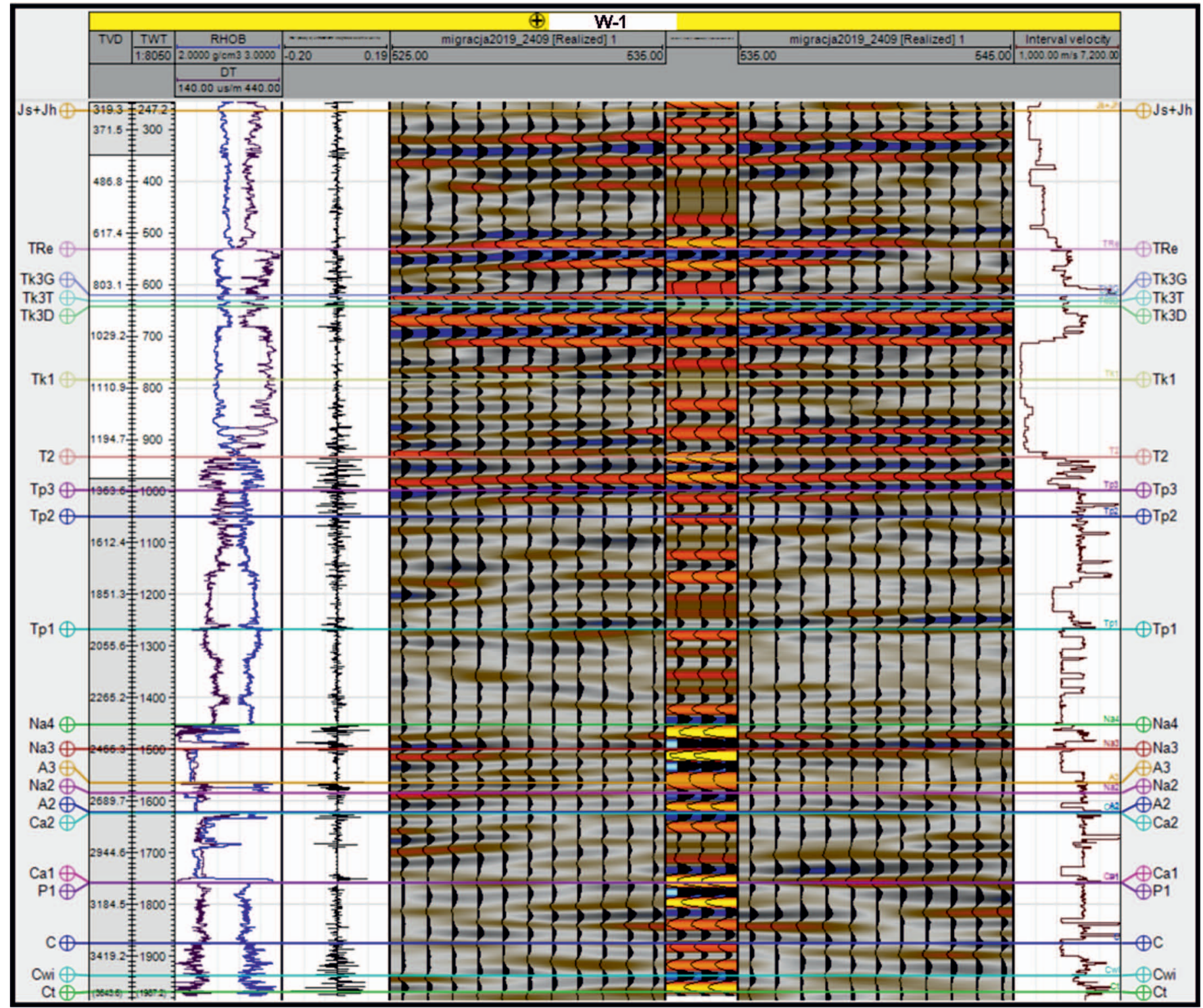

Rys. 6. Dopasowanie trasy syntetycznej do fragmentu sekcji sejsmicznej w pozycji otworu W-1

Fig. 6. Seismic-to-well tie in the W-1 well 


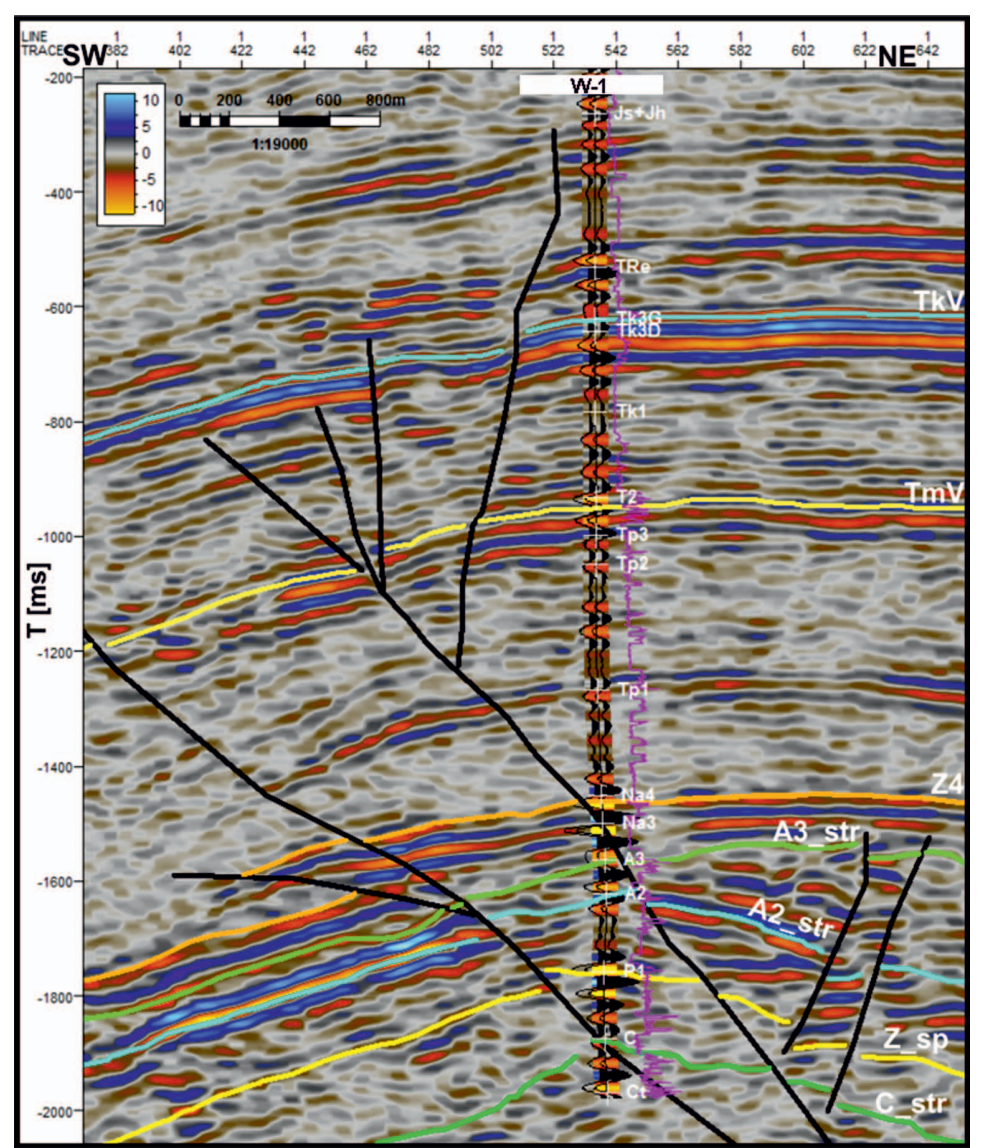

Rys. 7. Fragment czasowego profilu sejsmicznego $\mathrm{nr} 1 \mathrm{z}$ dopasowaniem trasy syntetycznej w pozycji otworu W-1

Fig. 7. Fragment of seismic section No. 1 and synthetic trace in the W-1 well position

\section{Charakterystyka uzyskanego obrazu sejsmicznego}

Wyniki bieżących obliczeń migracji czasowej po składaniu prezentowane są na rysunkach 8,9 12, 15-20. Rysunek 10 przedstawia wersję migracji czasowej otrzymaną w pierwszym etapie pracy, a rysunki 11 i 14 - archiwalną migrację czasową.

Porównanie bieżącego obrazu sejsmicznego (rys. 8, $9,12,15-20)$ z obrazem uzyskanym w pierwszym etapie prac (rys. 10) wypada na korzyść opracowania bieżącego. Szczególnie poprawa ta jest widoczna w odtworzeniu po zastosowaniu procedury median filter (rys. 11). W opracowaniu bieżącym widać lepszą ciągłość zapisu i mniejsze zróżnicowanie dynamiki amplitud. Bieżący obraz pozbawiony jest szumów występujących uprzednio w postaci pozbawionych ciągłości przypadkowych refleksów. Bardzo wyraźnie obrazuje się to w części SW profilu. Obserwuje się również większą rozdzielczość oraz pojawienie się dodatkowych refleksów sejsmicznych nieobserwowanych na wersji wcześniejszej, co przekłada się na większe zróżnicowanie facjalne w obrębie utworów mezozoicznych. Widoczne jest to głównie w środkowej i NE części profilu. Również w obrębie utworów cechsztynu lepiej manifestują się zmiany litofacjalne, wynikające głównie ze zmian miąższości pomiędzy solami a anhydrytem. Poprawa zapisu sejsmicznego obejmuje także utwory podcechsztyńskie, w obrębie których pojawiło się więcej ciągłych refleksów w stosunku do wersji

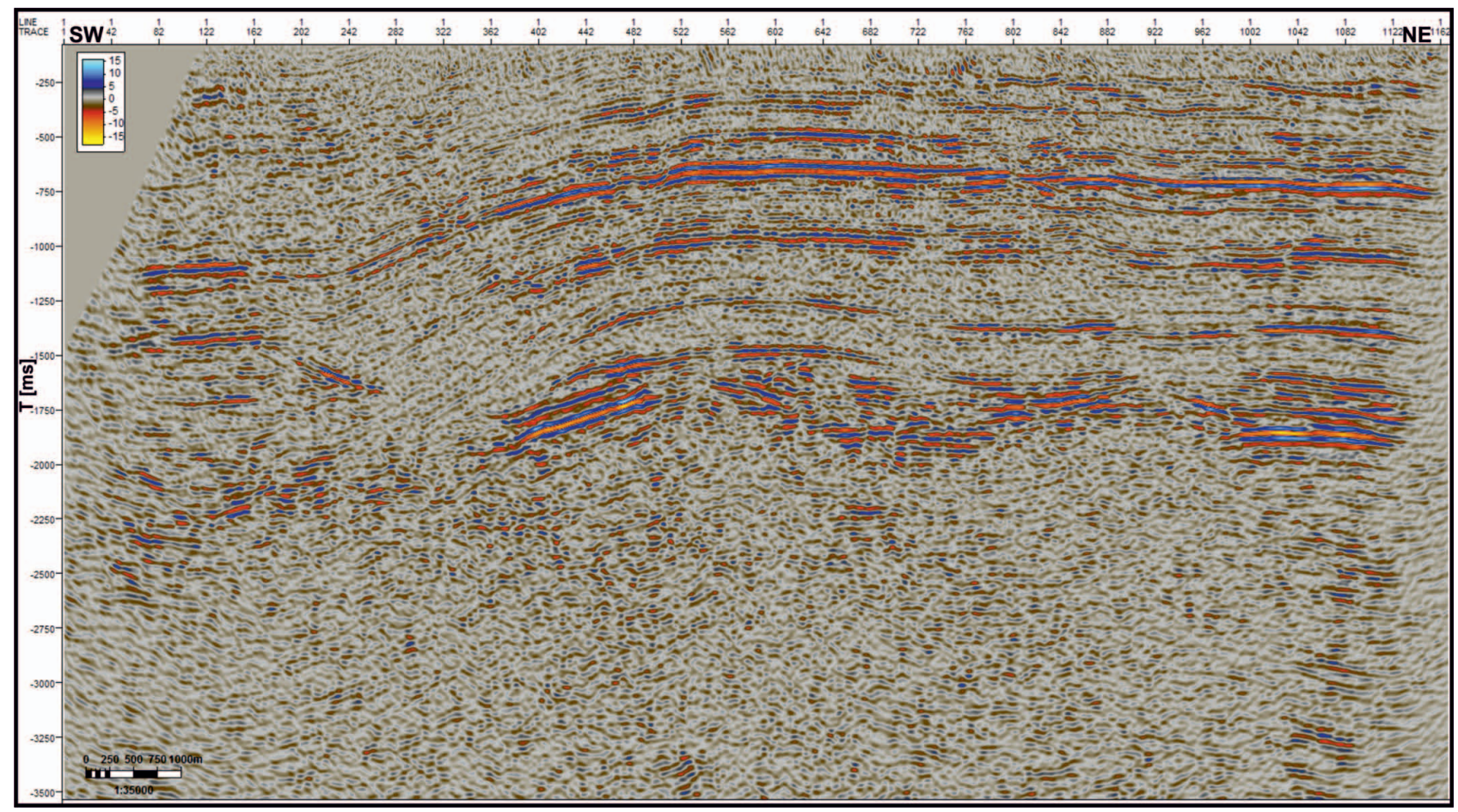

Rys. 8. Profil sejsmiczny nr 1. Migracja czasowa wykonana dla pola prędkości interwałowych w obecnym etapie

Fig. 8. Seismic section No. 1. Post stack time migration made for the interval velocities at the current stage 
z pierwszej części opracowania. Mimo dalszej poprawy obraz sejsmiczny w obrębie wyżej wspomnianych utworów nadal nie pozwala na poprawne i szczegółowe odzwierciedlenie budowy geologicznej w ich obrębie. Związane jest to głównie (pomijając słabą jakość zapisu sejsmicznego związanego z akwizycją danych sejsmicznych z tego przedziału) z brakiem poprawnego pola prędkości w tym interwale, który z kolei wynika z braku danych otworowych.

Aktualny obraz sejsmiczny pozwolił na dokładniejszą interpretację strukturalną badanego ośrodka geologicznego niż

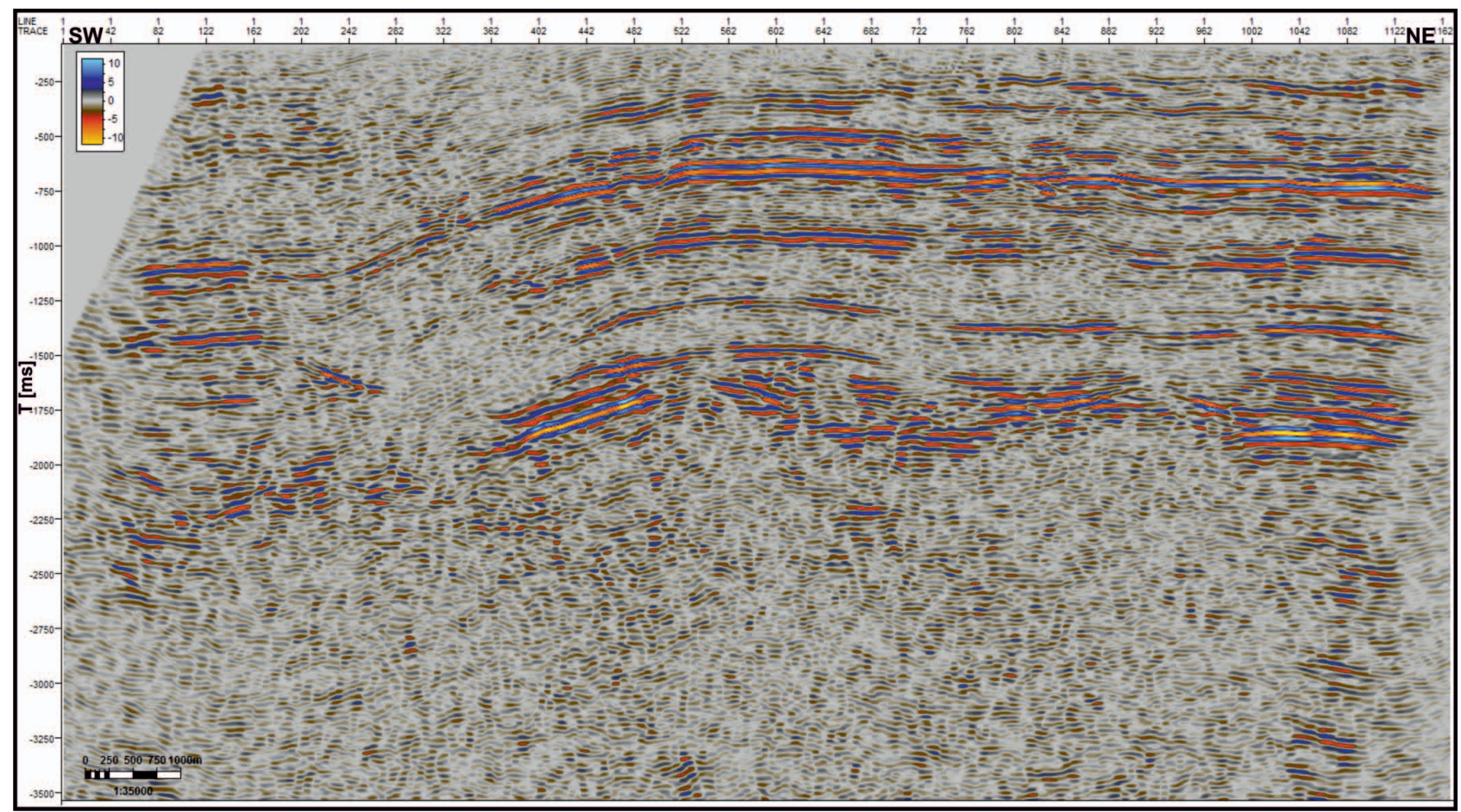

Rys. 9. Profil sejsmiczny nr 1. Migracja czasowa wykonana dla pola prędkości interwałowych w obecnym etapie z użyciem procedury median filter

Fig. 9. Seismic section No. 1. Poststack time migration made for the interval velocities at the current stage after apply median filter procedure

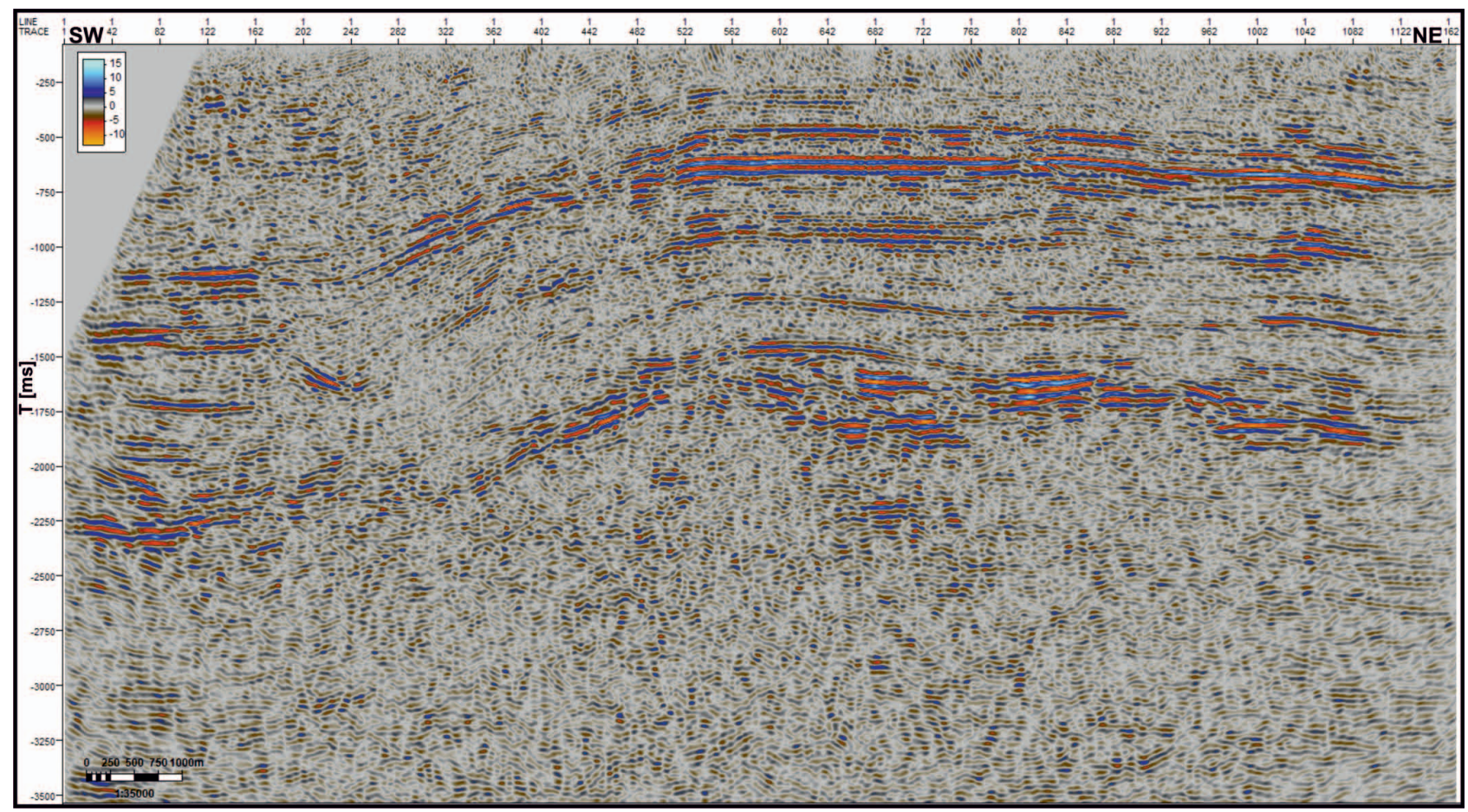

Rys. 10. Profil sejsmiczny nr 1. Migracja czasowa wykonana dla pola prędkości interwałowych (poprzedni etap)

Fig. 10. Seismic section No. 1. Poststack time migration made for the interval velocities (the previous stage) 


\section{NAFTA-GAZ}

w pierwszym etapie opracowania. Można to zauważyć np. w części SW profilu w obrębie ugięcia strukturalnego, którego budowa w bieżącym obrazie jest bardziej precyzyjnie oddana. Lepiej i pewniej obrazują się strefy dyslokacyjne, co pozwala na bardziej szczegółową interpretację tektoniki.
Rysunki 12 i 13 przedstawiają porównanie interpretacji bieżącej i poprzedniej. W wersji bieżącej widoczna jest większa liczba dyslokacji oraz nowa pozycja uskoków uprzednio wyinterpretowanych. Największe zmiany obserwuje się w części SW i NE profilu. Ponadto w obrazie bieżącym

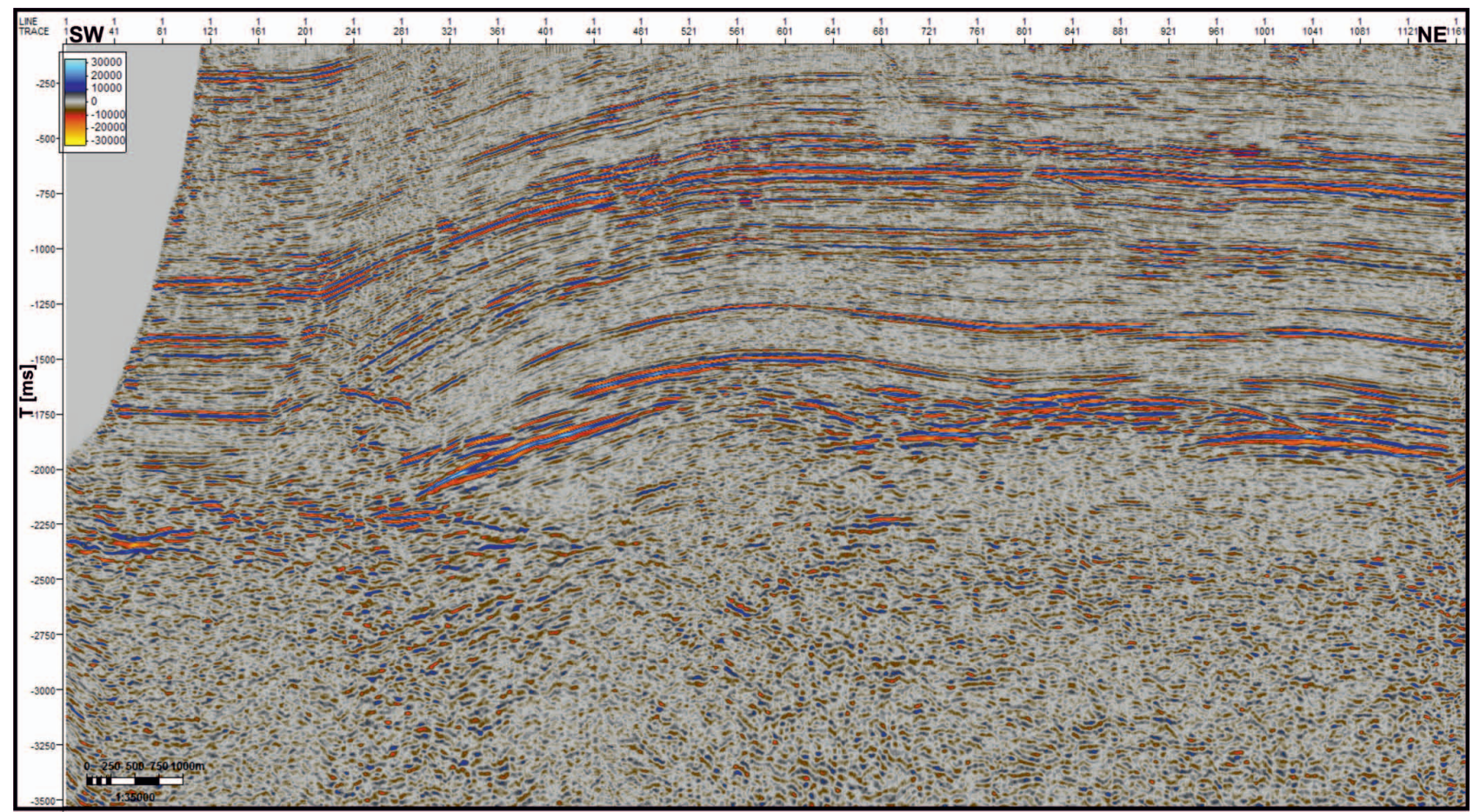

Rys. 11. Profil sejsmiczny nr 1. Migracja czasowa po składaniu - wersja archiwalna

Fig. 11. Seismic section No. 1. Poststack time migration - archival version

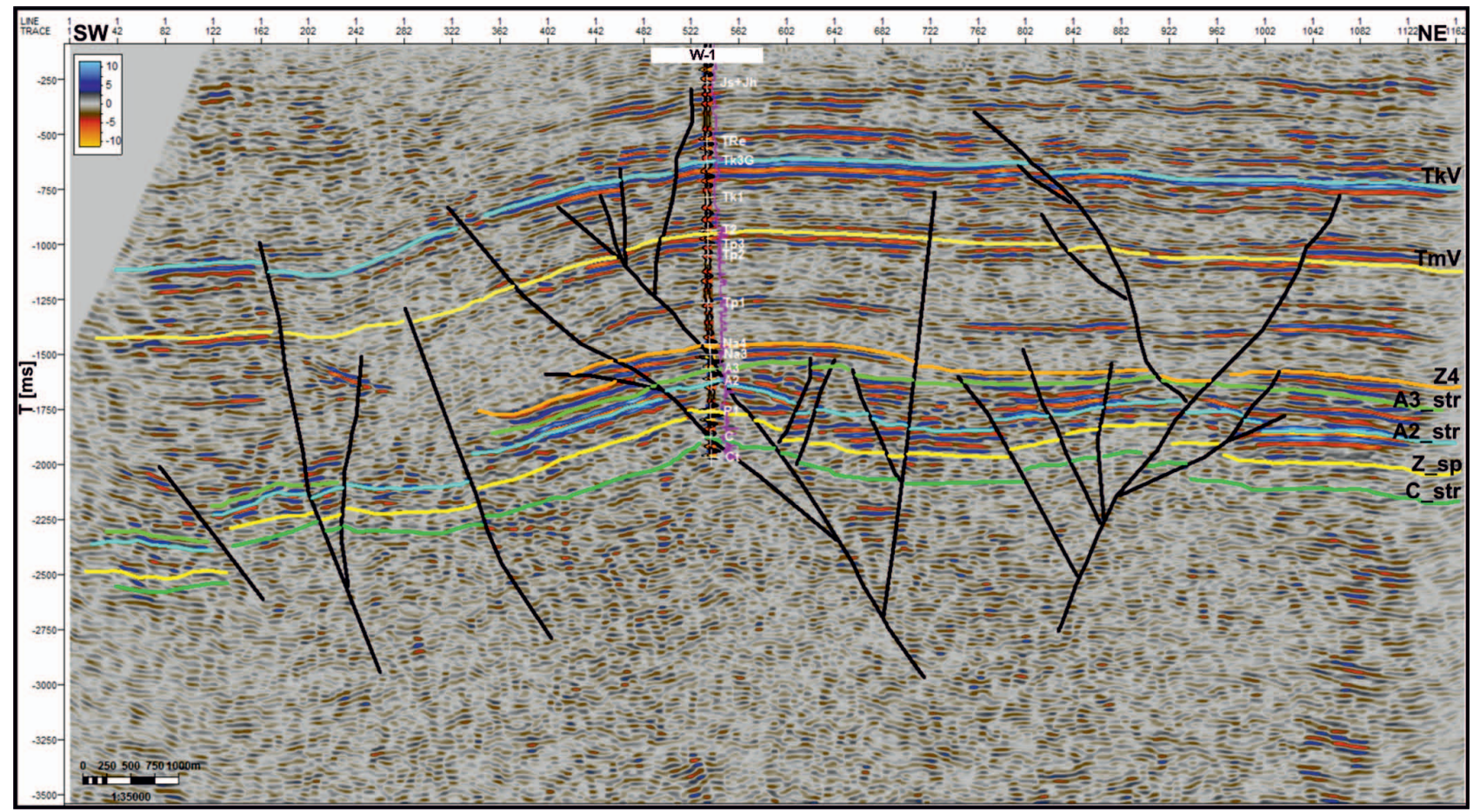

Rys. 12. Profil sejsmiczny nr 1. Migracja czasowa po składaniu wykonana dla pola prędkości interwałowych w obecnym etapie z użyciem procedury median filter z bieżącą interpretacją strukturalną

Fig. 12. Seismic section No. 1. Poststack time migration made for the interval velocities at the current stage after applying the median filter procedure with current structural interpretation 
uskoki zdecydowanie zagłębiają się w podłoże podpermskie. Nowy obraz pozwala na korelację horyzontów C_str, Z_sp, Potwierdza to przedstawioną w pierwszym etapie opracowania koncepcję zjawiska reaktywacji starszych generacji uskoków w historii badanego rejonu. Zdecydowanej zmiaA2_str i A3_str na całości profilu, co nie było możliwe na wcześniejszej wersji (rys. 12, 15-20).

nie i poprawie uległa interpretacja horyzontów sejsmicznych. staci przetworzonego profilu sejsmicznego (rys. 8, 9, 12,
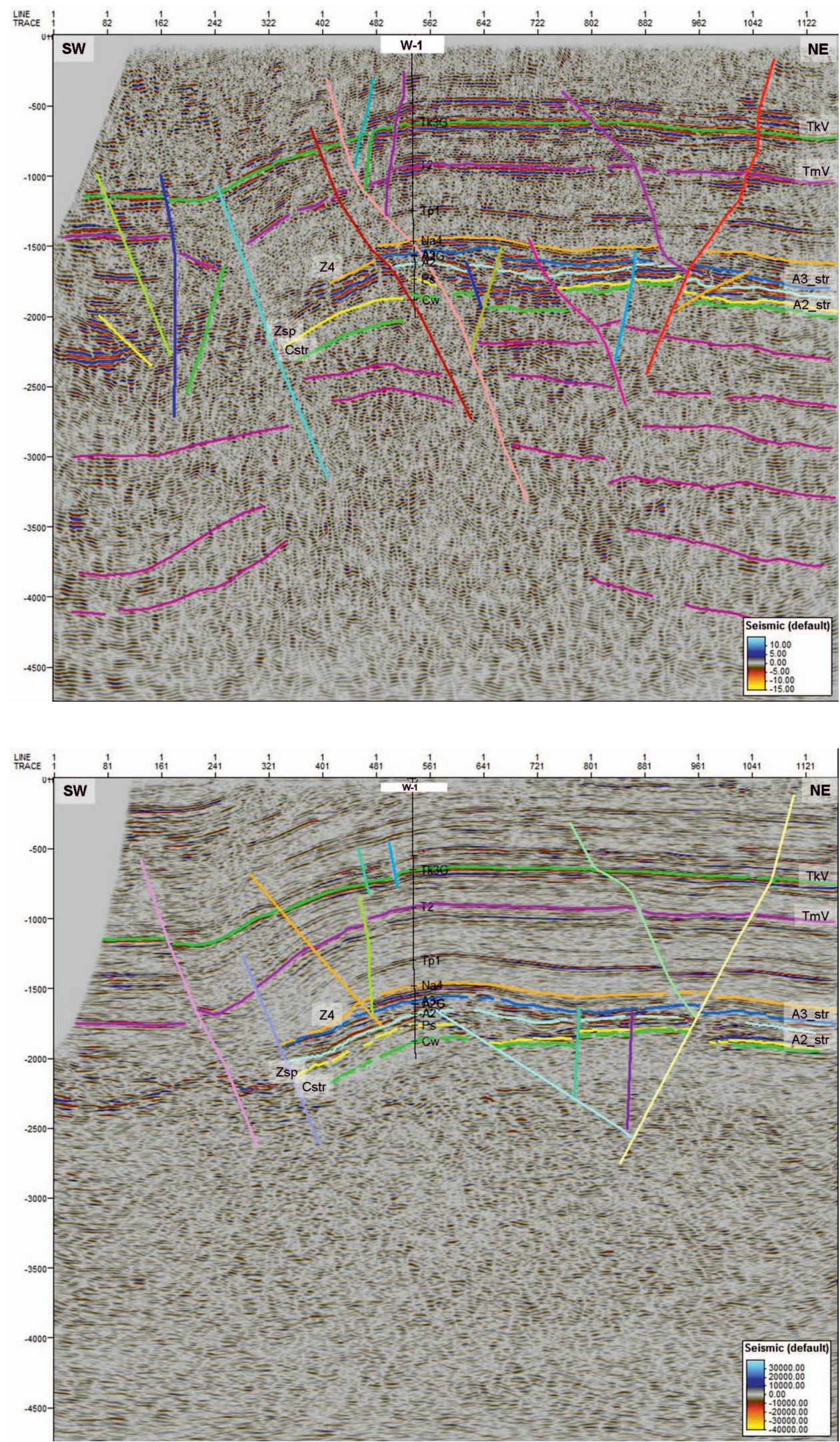

Rys. 13. Profil sejsmiczny nr 1. Migracja czasowa po składaniu wykonana dla pola prędkości interwałowych $\mathrm{z}$ poprzedniego etapu $\mathrm{z}$ interpretacją strukturalną

Fig. 13. Seismic section No. 1. Poststack time migration made for the interval velocities at the previous stage with current structural interpretation

Rys. 14. Profil sejsmiczny nr 1. Migracja czasowa po składaniu - wersja archiwalna $\mathrm{z}$ interpretacją strukturalną

Fig. 14. Seismic section No. 1.

Poststack time migration - archival version with interpretation 


\section{NAFTA-GAZ}

15-20) z wynikiem archiwalnym (rys. 11, 14), można zauważyć, że różnica jest znacząca. Uzyskany rezultat całkowicie zmienia obraz budowy geologicznej zaprezentowanej na wersji archiwalnej, co nowelizuje spojrzenie na badany rejon, a w konsekwencji sposób podejścia do poszukiwań węglowodorów.

\section{Atrybuty sejsmiczne}

Atrybuty sejsmiczne obliczone zostały w celu analizy uzyskanego obrazu sejsmicznego i wsparcia interpretacji strukturalnej. Ukazują one bądź eksponują elementy budowy strukturalnej i litofacjalnej, które nie są widoczne w amplitudowym zapisie sejsmicznym. Spośród wielu różnych obliczonych

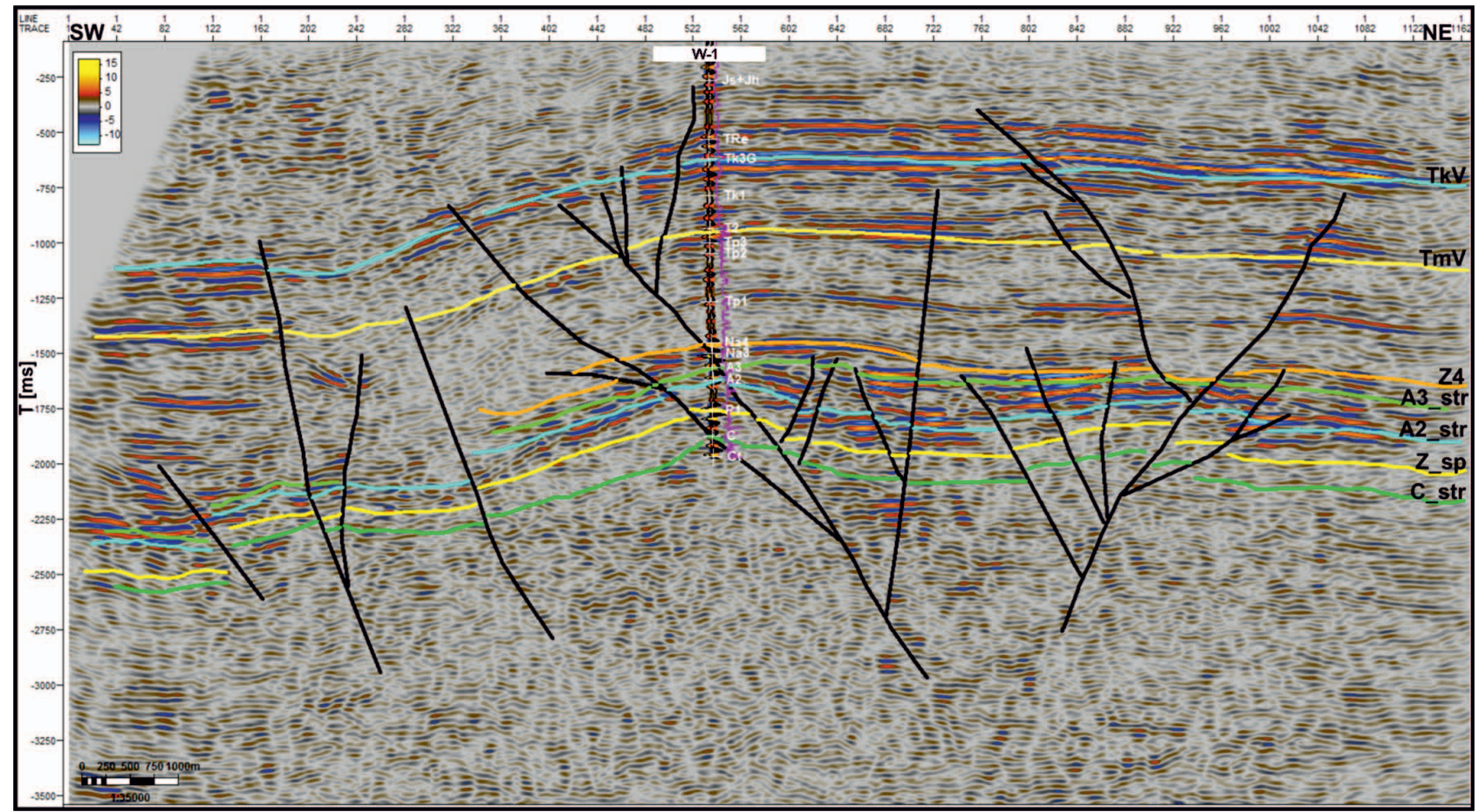

Rys. 15. Profil sejsmiczny nr 1 (migracja czasowa po składaniu) - atrybut Structural smoothing z bieżącą interpretacją strukturalną

Fig. 15. Seismic section No. 1 (post stack time migration) - Structural smoothing attribute with current structural interpretation

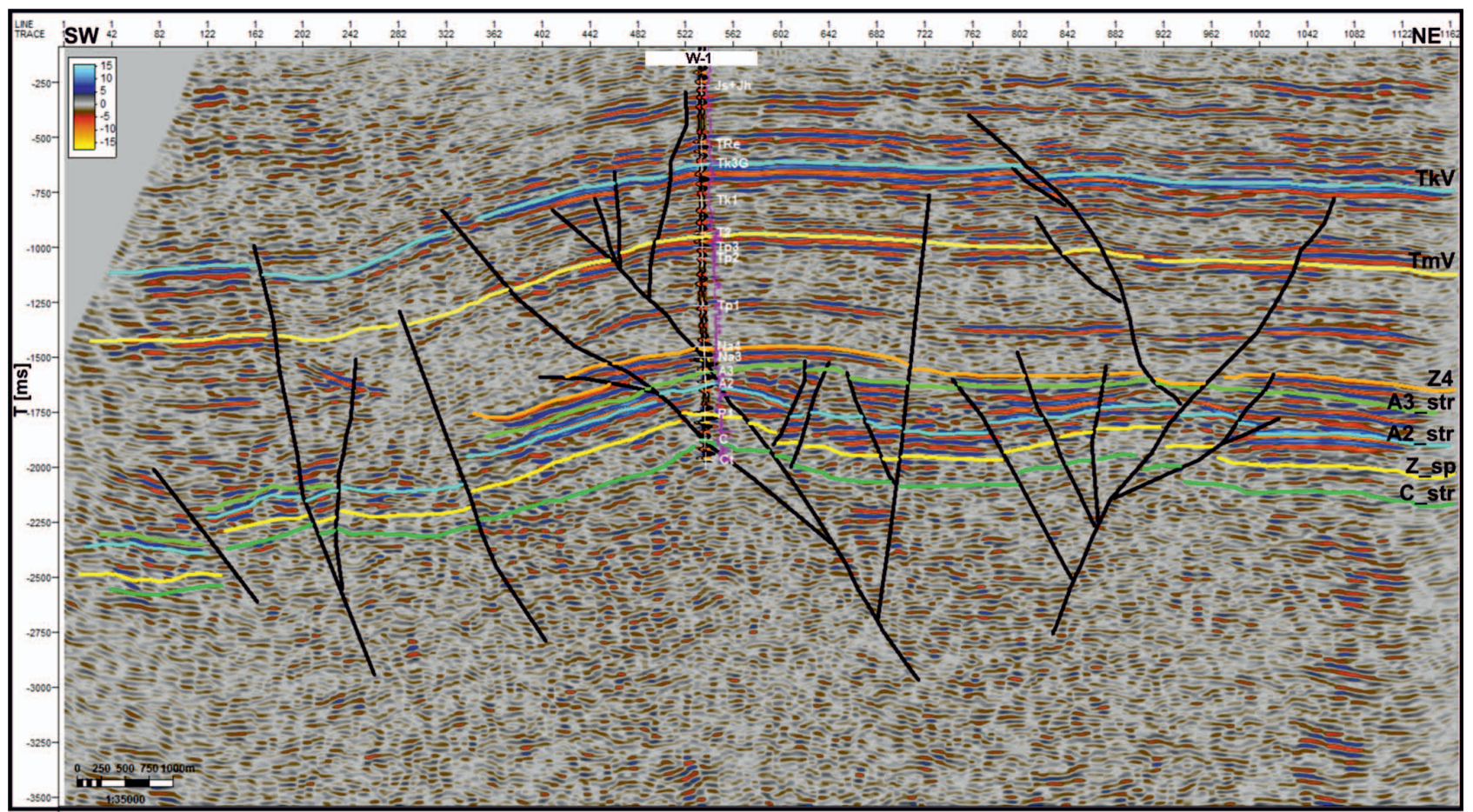

Rys. 16. Profil sejsmiczny nr 1 (migracja czasowa po składaniu) - atrybut Trace $A G C$ z bieżącą interpretacją strukturalną

Fig. 16. Seismic section No. 1 (post stack time migration) - Trace $A G C$ attribute with current structural interpretation 
atrybutów sejsmicznych wybrano takie, które w bieżącym obrazie sejsmicznym wyraźnie akcentują nowe elementy strukturalne, tj.: Structural smoothing, Trace AGC, Sweetness, Relative acoustic impedance, Cosine of phase, RMS Amplitude.

Atrybut Structural smoothing wygładza sygnał w celu zwiększenia ciągłości refleksów sejsmicznych (Pedersen et al.,
2002). Trace $A G C$ wyrównuje wartości amplitud, w wyniku czego ulega poprawie ciągłość refleksów i bardziej uwidaczniają się strefy nieciągłości. RMS Amplitude, obliczany jako kwadrat amplitudy sygnału i nazywany często energią sygnału, wskazuje strefy o największej dynamice refleksów. Sweetness jest użyteczny do badania środowisk depozycyjnych i zmian

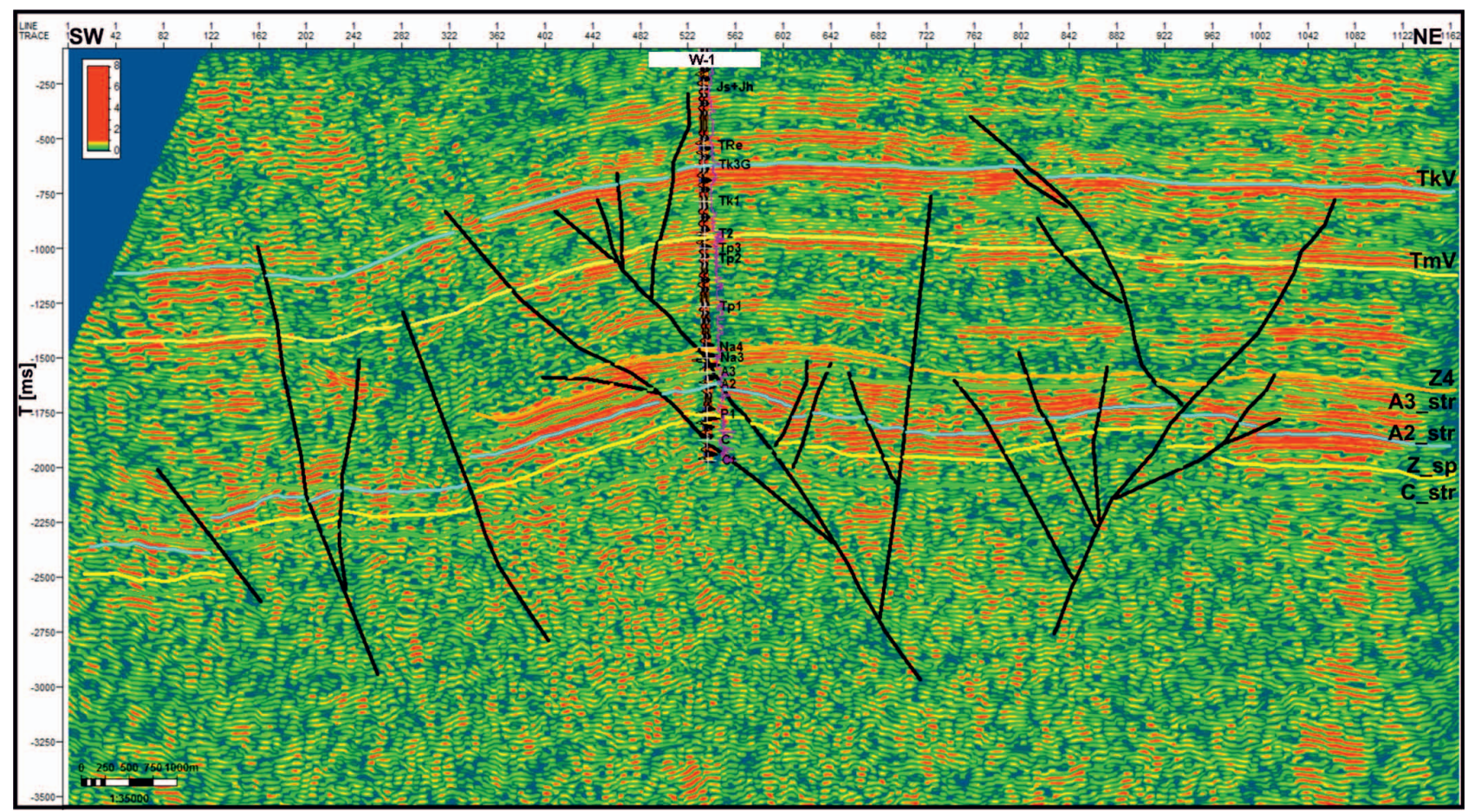

Rys. 17. Profil sejsmiczny nr 1 (migracja czasowa po składaniu) - atrybut Sweetness z bieżącą interpretacją strukturalną

Fig. 17. Seismic section No. 1 (post stack time migration) - Sweetness attribute with current structural interpretation

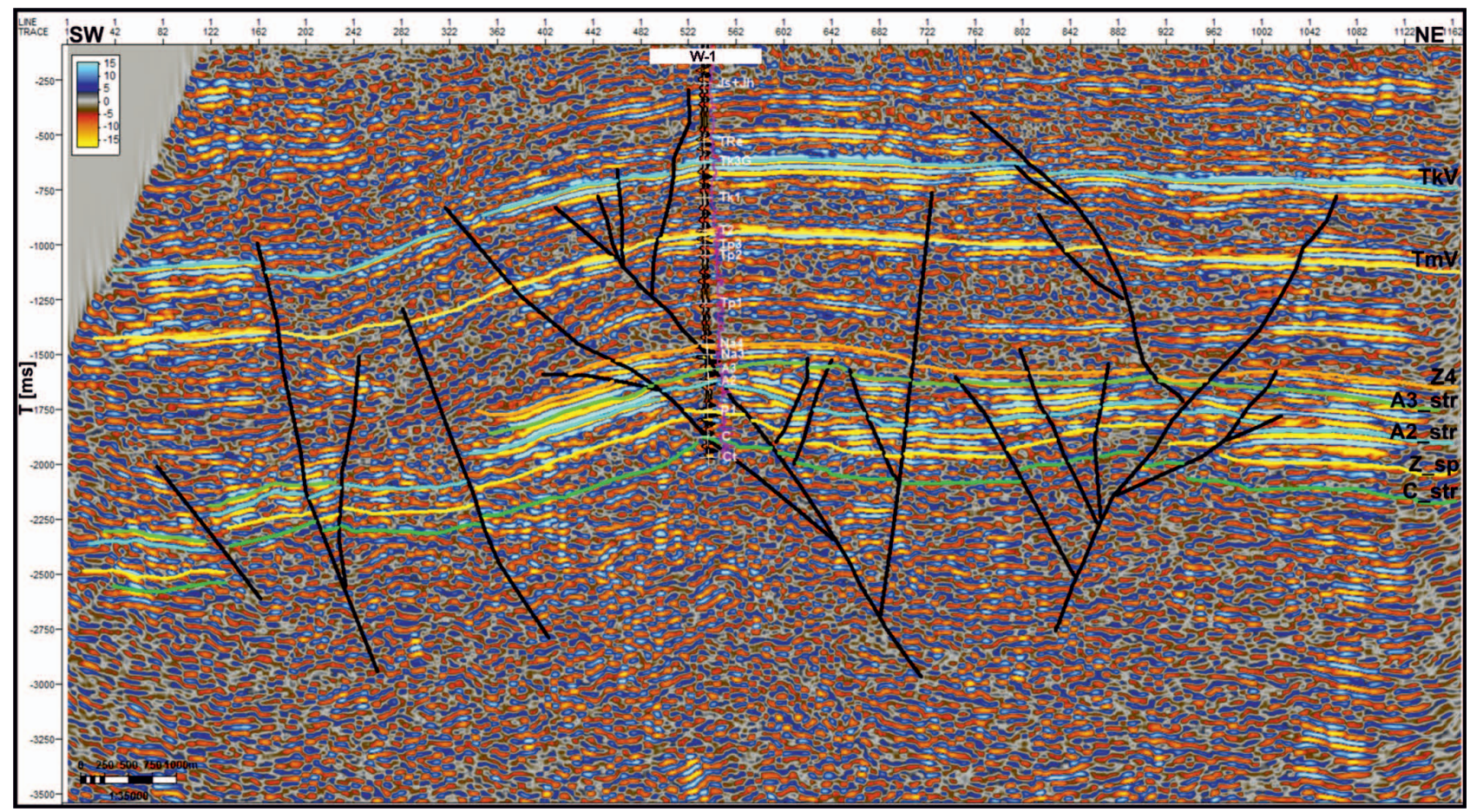

Rys. 18. Profil sejsmiczny nr 1 (migracja czasowa po składaniu) - atrybut Relative acoustic impedance z bieżącą interpretacją strukturalną

Fig. 18. Seismic section No. 1 (post stack time migration) - Relative acoustic impedance attribute with current structural interpretation 
litofacjalnych. Relative acoustic impedance jest wykorzystywany do analiz litofacjalnych. Cosine of phase znajduje zastosowanie głównie w detekcji nieciągłości, a także w analizie ciągłości refleksów. Wszystkie atrybuty zostały obliczone na wersji migracji czasowej po składaniu po użyciu procedury median filter.
Ciągłość refleksów sejsmicznych najlepiej obrazują atrybuty Structural smoothing (rys. 15) i Trace AGC (rys. 16). Strefy nieciągłości obserwuje się szczególnie na atrybutach: Sweetness (rys. 17), Cosine of phase (rys. 19). Zmiany litofacjalne najlepiej obserwuje się na: Sweetness (rys. 17), Relative acoustic impedance (rys. 18) i RMS Amplitude (rys. 20).

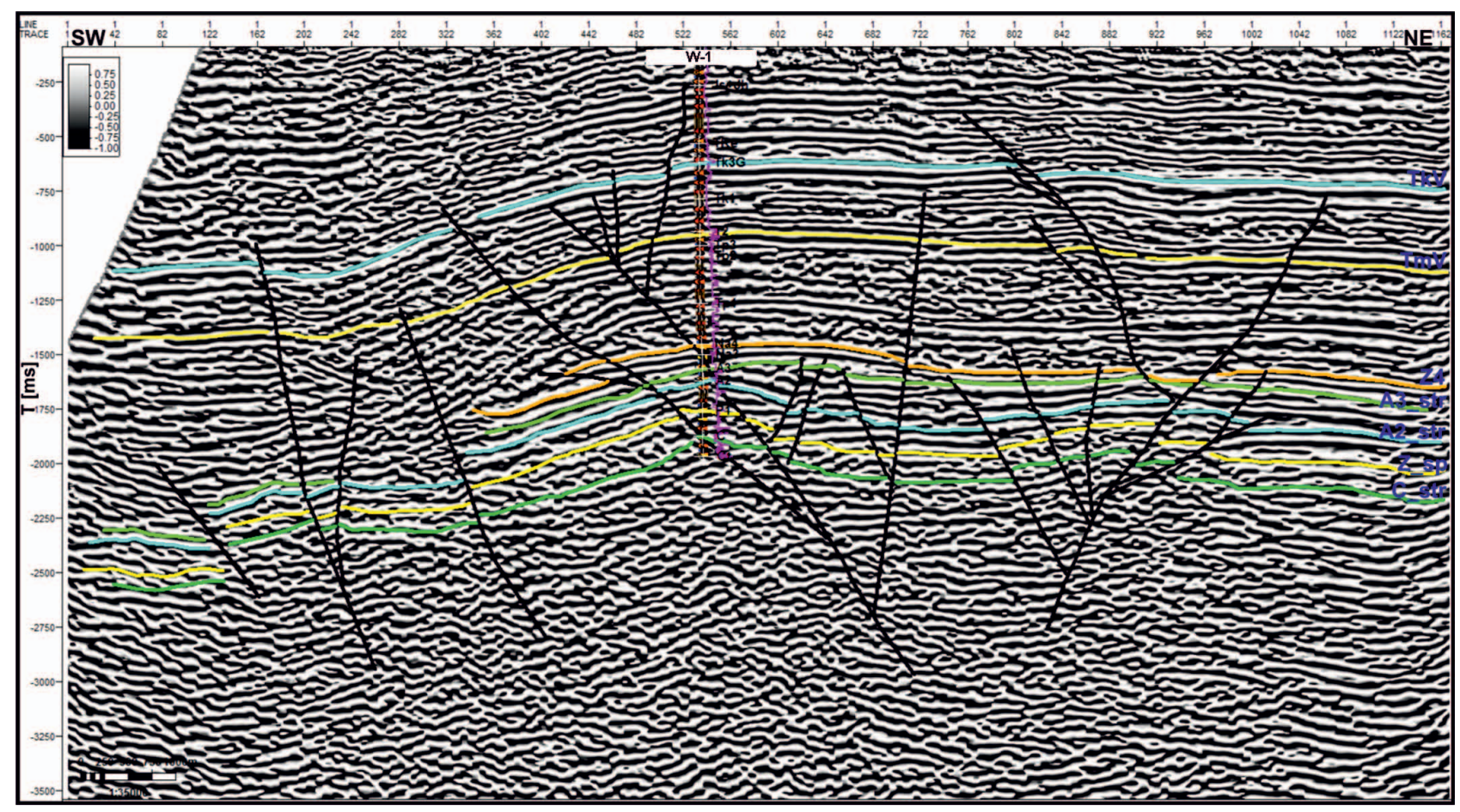

Rys. 19. Profil sejsmiczny nr 1 (migracja czasowa po składaniu) - atrybut Cosine of Phase z bieżącą interpretacją strukturalną Fig. 19. Seismic section No. 1 (post stack time migration) - Cosine of Phase attribute with current structural interpretation

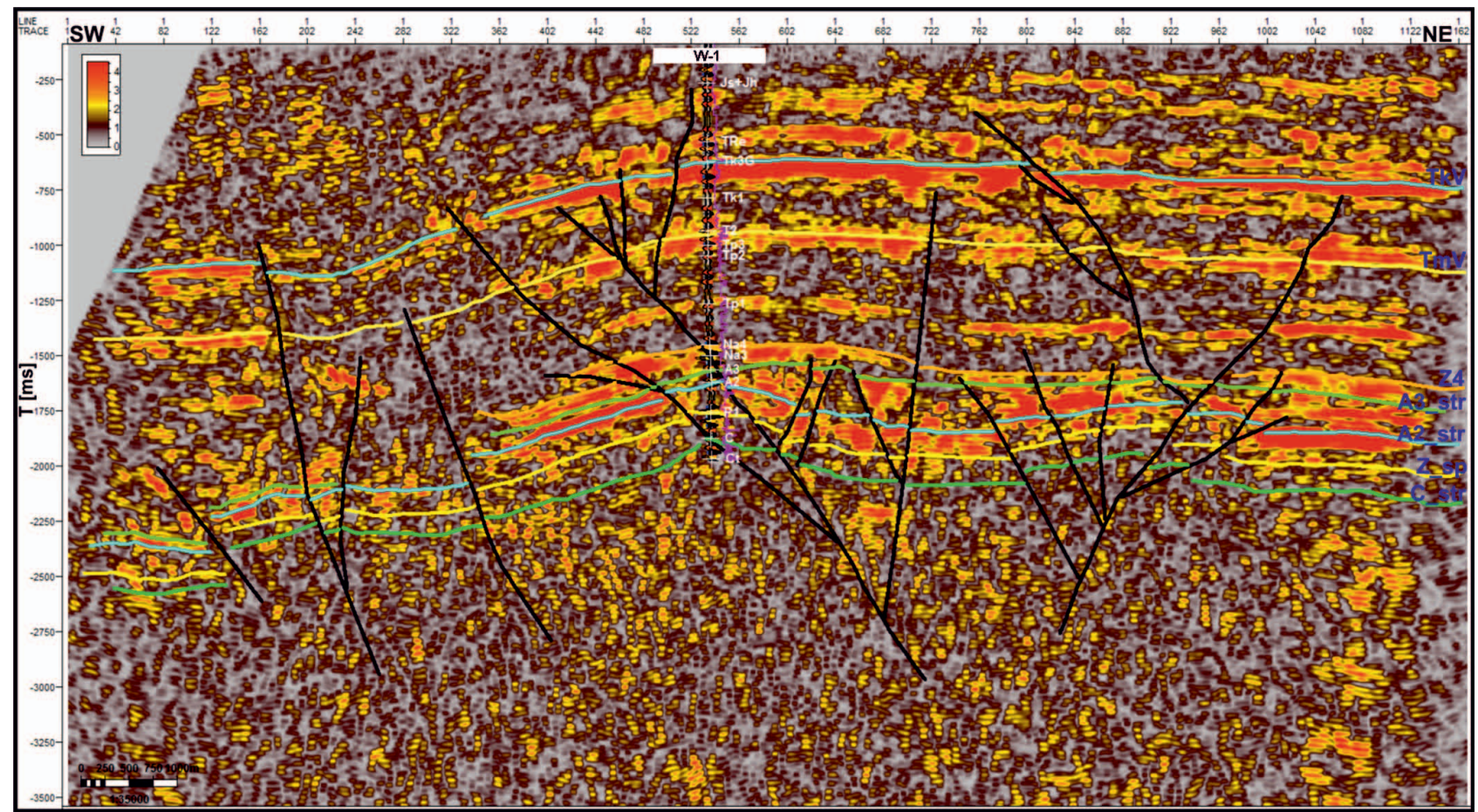

Rys. 20. Profil sejsmiczny nr 1 (migracja czasowa po składaniu) - atrybut RMS Amplitude z bieżącą interpretacją strukturalną Fig. 20. Seismic section No. 1 (post stack time migration) - RMS Amplitude attribute with current structural interpretation 


\section{Podsumowanie i wnioski}

Omawiana praca badawcza była kontynuacją próby zastosowania takich procedur przetwarzania sejsmiki 2D w rejonie Pomorza Zachodniego, które mogą poprawić zapis sejsmiczny w obrębie utworów podcechsztyńskich.

Zastosowana obecnie sekwencja przetwarzania, która została opracowana w ramach poprzednich tematów statutowych (Bajewski et al., 2016, 2017b, 2018b), a następnie zmodyfikowana na potrzeby niniejszej pracy, pozwoliła na jeszcze lepszą poprawę obrazu sejsmicznego, ale głównie w obrębie utworów permsko-mezozoicznych. Umożliwiło to bardziej szczegółową interpretację płaszczyzn dyslokacji i przebiegu horyzontów sejsmicznych. Wyinterpretowany obraz tektoniczny uległ modyfikacji i uszczegółowieniu w porównaniu z wersją przedstawioną $\mathrm{w}$ części pierwszej opracowania.

Poprawie uległ również obraz sejsmiczny w podłożu cechsztynu, co było głównym celem niniejszej pracy. Pojawiły się fragmenty refleksów potwierdzające zarysowaną we wcześniejszej wersji budowę podłoża - potwierdziło się, że część uskoków obserwowanych w permo-mezozoiku jest głęboko zakorzenionych w utworach podcechsztyńskich (paleozoicznych). Nadal nie jest to obraz, który pozwalałby na w pełni wiarygodną i szczegółową interpretację, zwłaszcza pod kątem poszukiwań złóż węglowodorów. Główną przyczyną takiego stanu rzeczy jest brak poprawnego rozkładu prędkości w ich obrębie, wynikający z niedostatecznej ilości danych otworowych w rejonie badań. Analiza prędkości składania w tym przedziale czasowym jest obarczona zbyt dużymi błędami, a brak danych otworowych nie pozwala na konstrukcję poprawnego modelu prędkości do migracji.

Wyniki prezentowanej pracy pokazują, że przy zastosowaniu odpowiednich procedur, doborze odpowiednich parametrów i poprawnego pola prędkości istnieje duży potencjał w zakresie reprocessingu archiwalnych profili sejsmicznych $\mathrm{z}$ analizowanego rejonu, a wysiłki w celu uzyskania lepszego obrazu sejsmicznego dla utworów podłoża cechsztynu powinny się koncentrować przede wszystkim na poprawnym odwzorowaniu pola prędkości w ich obrębie.

Uzyskany obecnie obraz sejsmiczny w dużym stopniu zmienia spojrzenie na budowę geologiczną badanego rejonu, przedstawioną na podstawie wersji archiwalnej. Otrzymane w ten sposób nowe dane dotyczące budowy strukturalnej mogą w konsekwencji skutkować opracowaniem nowych koncepcji poszukiwań złóż węglowodorów.

Artykuł powstał na podstawie pracy statutowej pt.: Poprawa obrazowania struktur podcechsztynskich na podstawie reprocessingu sejsmiki $2 D$ w rejonie Pomorza Zachodniego. Cz. II - praca INiG - PIB na zlecenie MNiSW; nr zlecenia 0072/SR/2019, nr archiwalny DK-4100-0062/2019.

\section{Literatura}

Bajewski Ł., Urbaniec A., Wilk A., Bartoń R., 2016. Zwiększenie dokładności odwzorowania ośrodka geologicznego z obszaru Karpat na podstawie przetwarzania sejsmiki powierzchniowej 2D i otworowej. Praca statutowa INiG-PIB, nr zlec. 0019/ SR/2016, Archiwum Instytutu Nafty i Gazu - Państwowego Instytutu Badawczego, Kraków.

Bajewski Ł., Urbaniec A., Wilk A., Bartoń R., 2017a. Poprawa dokładności odwzorowania budowy geologicznej w obrazie sejsmicznym z obszaru Karpat zewnętrznych. Nafta-Gaz, 7: 447-454. DOI: 10.18668/NG.2017.07.02.

Bajewski Ł., Urbaniec A., Wilk A., Bartoń R., 2017b. Zwiększenie dokładności odwzorowania ośrodka geologicznego z obszaru Karpat na podstawie przetwarzania sejsmiki powierzchniowej 2D i otworowej. Cz. II. Praca statutowa INiG-PIB, $n r$ zlec. 0020/SR/2017, Archiwum Instytutu Nafty i Gazu - Państwowego Instytutu Badawczego, Kraków.

Bajewski Ł., Wilk A., Bartoń R., Urbaniec A., 2018a. Zwiększenie dokładności odwzorowania ośrodka geologicznego z wybranego obszaru Karpat zewnętrznych na podstawie reprocessingu archiwalnych profili sejsmicznych 2D. Prace Naukowe Instytutu Nafty i Gazu - Państwowego Instytutu Badawczego, 222: 1-180. DOI: $10.18668 / \mathrm{PN} 2018.222$.

Bajewski Ł., Wilk A., Urbaniec A., Bartoń R., 2018b. Poprawa obrazowania struktur podcechsztyńskich na podstawie reprocessingu sejsmiki 2D w rejonie Pomorza Zachodniego. Praca statutowa INiG-PIB, nr zlec. 0031/SR/2018, Archiwum Instytutu Nafty i Gazu-Państwowego Instytutu Badawczego, Kraków.

Bajewski Ł., Wilk A., Urbaniec A., Bartoń R., 2019. Poprawa obrazowania struktur podcechsztyńskich na podstawie reprocessingu sejsmiki 2D w rejonie Pomorza Zachodniego. Nafta-Gaz, 4: 195-204. DOI: 10.18668/NG.2019.04.01.

Dadlez R., 1978. Podpermskie kompleksy skalne w strefie KoszalinChojnice. Kwartalnik Geologiczny, 22: 269-301.

Grad M., Keller G.R., Thybo H., Guterch A., POLONAISE Working Group, 2002. Lower lithospheric structure beneath the TransEuropean Suture Zone from POLONAISE'97 seismic profiles. Tectonophysics, 360: 153-168.

Grechka V., Mateeva A., Gentry C., Jorgensen P., Lopez J., Franco G., 2007. Estimation of seismic anisotropy from P-wave VSP data. The Leading Edge, 26: 765. DOI: 10.1016/ S0040-1951(02)00350-5.

Matyja H., 1993. Upper Devonian of Western Pomerania. Acta Geol. Pol., 42: 27-94.

Matyja H., 2006. Stratygrafia i rozwój facjalny osadów dewonu i karbonu w basenie pomorskim i w zachodniej części basenu bałtyckiego a paleogeografia północnej części TESZ w późnym paleozoiku. Prace Państwowego Instytutu Geologicznego, 186: 79-122.

Matyja H., Turnau E., Żbikowska B., 2000. Lower Carboniferous (Mississippian) stratigraphy of northwestern Poland: conodont, miospore and ostracod zones compared. Ann. Soc. Geol. Pol., 70: $193-217$.

Nawrocki J., Poprawa P., 2006. Development of Trans-European Suture Zone in Poland: from Ediacaran rifting to Early Palaeozoic accretion. Geol. Quart., 50(1): 59-76.

Pedersen S.I., Randen T., Sønneland L., 2002. Automatic extraction of fault surfaces from three-dimensional seismic data. Expanded Abstract, Int. Mtg., Soc. Exploration Geophys., 512-515.

Pevzner R., Gurevich B., Duncan G., 2009. Estimation of Azimuthal Anisotropy from VSP Data Using Multicomponent Velocity Analysis. $71^{\text {st }}$ EAGE Conference, Amsterdam, The Netherlands, 8-11 June. 
Pharaoh T.C., 1999. Palaeozoic terranes and their lithospheric boundaries within the Trans-European Suture Zone (TESZ): a review. Tectonophysics, 314: 17-41.

Świdrowska J., Hakenberg M., 1996. Palaeotectonic evolution of the Koszalin-Chojnice Late Devonian basin (Western Pomerania, Northern Poland). Bull. Pol. Acad. Sc. Earth Sc., 44: 17-36.

Wagner R., 1994. Stratygrafia i rozwój basenu cechsztyńskiego na Niżu Polskim. Prace Państwowego Instytutu Geologicznego, 146: 1-71.

Wilk A., Bartoń R., Bajewski Ł., Urbaniec A., 2017. Budowa pola prędkości na potrzeby migracji czasowej i głębokościowej 2D przed i po składaniu w trudnych rejonach geologicznych. Praca statutowa INiG-PIB, nr zlec. 0021/SR/2017, Archiwum Instytutu Nafty i Gazu - Państwowego Instytutu Badawczego, Kraków.

Wilk A., Bartoń R., Bajewski Ł., Urbaniec A., 2018. Budowa pola prędkości na potrzeby migracji czasowej po składaniu w trudnych rejonach geologicznych na przykładzie Karpat fliszowych w południowo-wschodniej Polsce. Nafta-Gaz, 10: 723-731. DOI: 10.18668/NG.2018.10.03.

Żelaźniewicz A., Aleksandrowski P., Buła Z., Karnkowski P.H., Konon A., Oszczypko N., Ślączka A., Żaba J., Żytko K., 2011. Regionalizacja tektoniczna Polski. Komitet Nauk Geologicznych PAN, Wrocław.

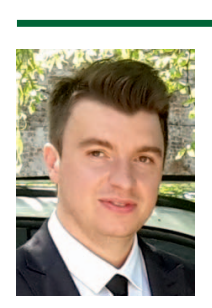

Mgr inż. Łukasz BAJEWSKI

Główny specjalista inżynieryjno-techniczny

w Zakładzie Sejsmiki

Instytut Nafty i Gazu - Państwowy Instytut Badawczy ul. Lubicz $25 \mathrm{~A}$

31-503 Kraków

E-mail: lukasz.bajewski@inig.pl

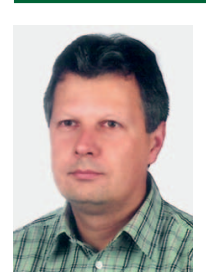

Dr Andrzej URBANIEC

Adiunkt w Zakładzie Sejsmiki

Instytut Nafty i Gazu - Państwowy Instytut Badawczy

ul. Lubicz 25 A

31-503 Kraków

E-mail:andrzej.urbaniec@inig.pl

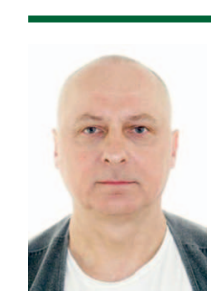

Mgr inż. Aleksander WILK

Główny specjalista inżynieryjno-techniczny

w Zakładzie Sejsmiki

Instytut Nafty i Gazu - Państwowy Instytut Badawczy ul. Lubicz 25 A

31-503 Kraków

E-mail:wilka@inig.pl

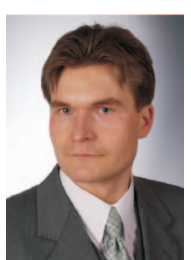

Dr inż. Robert BARTOŃ

Adiunkt w Zakładzie Sejsmiki

Instytut Nafty i Gazu - Państwowy Instytut Badawczy

ul. Lubicz 25 A

31-503 Kraków

E-mail: robert.barton@inig.pl

\section{OFERTA BADAWCZA ZAKŁADU SEJSMIKI}

przetwarzanie danych sejsmicznych Prestack i Postack;

modelowanie sejsmiczne na danych 2D / 3D;

interpretacja strukturalna i litofacjalna danych sejsmicznych 2D i 3D; by konwersji czas-gtębokość oraz migracii głębokościowej;

konstrukcja map powierzchniowych w domenie czasu i głębokości;

wieloatrybutowa charakterystyka ośrodka geologicznego;

analizy sejsmiczne AVO, AVAZ; oraz azymutu anizotropii); nego pomiaru PPS 3 C i pomiarów sejsmicznych 3D; na danych sejsmicznych: nego (PPS);

przetwarzanie i interpretacja pionowych profilowań sejsmicznych PPS 1C / 3C;

interpretacja danych sejsmicznych 2D, 3D oraz pomiarów sejsmiki otworowej PPS-3C;

budowa modeli prędkościowych w domenie czasu i głębokości (na podstawie danych sejsmicznych i geofizyki otworowej) na potrze-

podwyższenie rozdzielczości pionowej danych sejsmicznych przy wykorzystaniu pomiarów PPS;

poprawa rozdzielczości danych sejsmicznych z wykorzystaniem procedury dekompozycji spektralnej;

opracowanie i analiza map atrybutów sejsmicznych, inwersji sejsmicznej, dekompozycji spektralnej;

obliczanie inwersii symultanicznej oraz stochastycznej na danych sejsmicznych:

identyfikacja anizotropii typu HTI w ośrodku geologicznym przy użyciu danych sejsmicznych i otworowych (określenie intensywno

obliczanie parametrów anizotropii typu VTI i HTI oraz określenie gtównych kierunków szczelinowatości na podstawie wieloazymutal-

wyznaczanie obszarów perspektywicznych dla formacji tupkowych (sweet spots) oraz wskaźników DHI dla ztóż konwencjonalnych

prognozowanie ciśnień porowych na podstawie danych sejsmicznych i geofizycznych;

interpretacja parametrów petrofizycznych w przestrzeni okotootworowej w oparciu o pomiary pionowego profilowania sejsmicz-

kompleksowa interpretacja geologiczno-złożowa w oparciu zintegrowane dane geologiczne i geofizyczne (analiza cech makroskopowych rdzeni wiertniczych, objawy i wyniki prób złożowych, profilowania geofizyki otworowej, interpretacja sejsmiczna).

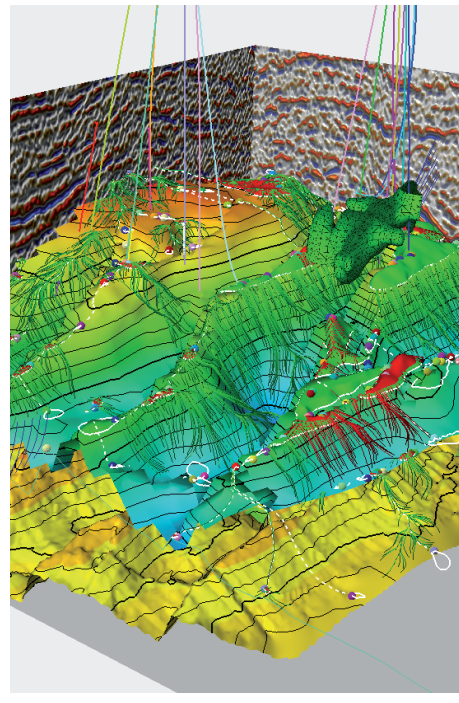

Kierownik: dr Andrzej Urbaniec Adres: ul. Bagrowa 1, 30-733 Kraków Telefon: 126177486 Faks: 126531665 E-mail: andrzej.urbaniec@inig.pl
INSTYTUT NAFTY I GAZU

- Państwowy Instytut Badawczy 